\title{
IMPLICATION OF REGIONAL TAX REGULATION ON THE INVESTMENT CLIMATE AND ITS REFERENCE TO OMNIBUS BILL ON TAXATION
}

\section{Debora Kristina Doloksaribu ${ }^{1}$}

${ }^{1}$ Fakultas Hukum, Magister Ilmu Hukum, Universitas Indonesia, email: debora.kristina91@ui.ac.id

\begin{abstract}
The granting of autonomy to the regions is intended to provide democratic space and public participation. Legal certainty in the administration of regional government specifically related to taxes is very crucial, especially for economic development, as it affects the investment climate. Any discrepancy between regional and central policies is seen as an obstacle in optimizing investment performance in the regions. The Government has proposed a Bill on General Provisions and Tax Facilities for Strengthening the Economy or also known as the Omnibus Bill on Taxation which regulates, among other things, regional tax and levy. The method used in this study is the type of legal research (normative) and carried out by examining library materials or secondary data in the form of various legal references, including primary, secondary, and tertiary materials. A descriptive technique is used in analyzing legal materials that have been collected. Writer opines that the Omnibus Bill is expected to provide business certainty, in the hope that it can increase investment. However, the discussion of the Omnibus Bill must be carefully done. There has to be a certainty and clarity of the intervention procedures of the central government so that it is carried out in a clear legal corridor.
\end{abstract}

\section{ARTICLE INFO}

Keywords:

Investor; Omnibus Law;

Regional Government

Cite this paper:

Doloksaribu, D. K., 2020. Implication of Regional Tax Regulation On The Investment Climate And Its Reference To Omnibus Bill On Taxation. Widya Yuridika: Jurnal Hukum, $3(2)$.

\section{INTRODUCTION}

Economic growth is a relevant benchmark for assessing the success of a country in managing its economy. ${ }^{1}$ Current favorite revenues in Indonesia are those from the tax sector. Tax is one of state revenue sources that serves as a source of funds for the government to finance its expenses, and tax is also a tool to regulate and implement

\footnotetext{
${ }^{1}$ Yolanda Nurlita Prastika, et. al, Analisis Efektivitas Pendapatan Pajak Reklame dan Kontribusinya Pada Pendapatan Pajak Daerah (Studi Pada Dinas Pendapatan Daerah Kota Malang), Jurnal Perpajakan (JEJAK), Vol. 6, No. 2, 2015, p. 1, retrieved from http://perpajakan.studentjournal.ub.ac.id/index.php/perpajakan/article/view/197
} 
government policies in the socio-economic field. ${ }^{2}$ Rochmat Soemitro defines tax as a commitment conferred by law that requires a person who meets the conditions specified by law (tatbestand) to pay a sum of money to the state treasury, of enforced nature, without getting a reward that can be directly designated, used to finance state expenditures (routine and development) and as a (driving, obstacle) tool to achieve goals outside the financial sector. ${ }^{3}$

Government policy in taxation sector is part of fiscal policy which will ultimately affect the achievement of the country's economic goals. ${ }^{4}$ Local economic development, especially the Municipal Government is the starting point for the implementation of development, so that region is expected to be more aware of the potential and needs of its own. One of the funding sources for the administration of the regional government is from the regional tax revenue. One thing that needs to be considered with regard to the strategy of regional tax development is that regional tax closely related to the effectiveness of tax collection on the existing tax objects. The collection of regional tax shall provide space to create creativity, innovations for investors, and business actors. ${ }^{5}$

It is important to consider the principle of tax regulation since taxes are the main source of income for the country, both at the central and regional levels, and bad regulation may increase the potential for corruption. In connection with the financing of regional autonomy, Law Number 33 of 2004 concerning Financial Balance between the Central Government and Regional Governments ("Law 33/2004") authorizes local governments to make policies related to revenue in the context of strengthening the regional government development and administration through the increase of revenue, particularly which results from the original regional revenues. ${ }^{6}$

Regional collection of tax and levy is regulated in Law Number 28 of 2009 concerning Regional Taxes and Regional Levies ("Law 28/2009"). Regional taxes and regional levies are important sources of regional income to finance the administration of regional government. ${ }^{7}$ Based on Law 28/2009, Regional Tax is an obligatory contribution to the Region owed by private individuals or entities of enforced nature based on the Law, without receiving direct compensation and used for the needs of the Region mostly for the welfare of the people. ${ }^{8}$ There are two objects of regional tax, i.e. the provincial tax which consists of 5 (five) types of tax, and the district/town tax, which consists of 11 (eleven)

\footnotetext{
${ }^{2}$ Ratih Kumala, Analisis Efektifitas Pajak Reklame Dalam Meningkatkan Penerimaan Pajak Daerah di Kota Bekasi, Jurnal Reformasi Administrasi, Vol. 6, No. 1, March 2019, p. 38, retrieved from ojs.stiami.ac.id > reformasi > article s download

${ }^{3}$ Rochmat Soemitro, Pengantar Singkat Hukum Pajak, Eresco, Bandung, 1992, p. 13.

${ }^{4}$ Yolanda Nurlita Prastika, et. al, Analisis Efektivitas Pendapatan Pajak Reklame...Loc. Cit.

${ }^{5}$ Dinas Pendapatan Daerah Kota Malang, Info PAD Kota Malang, Dinas Pendapatan Daerah Kota Malang, Malang, 2012, p. 28.

${ }^{6}$ Tjip Ismail, Pengaturan Pajak Daerah di Indonesia, Yellow Printing, Jakarta, 2008, p. 12.

7 Amelia Cahyadini, Pemisahan Peraturan Daerah Tentang Pajak dan Izin Reklame Sebagai Upaya Memaksimalkan Penerimaan Pajak, PJIH, Vol. 4, No. 1, 2017, p. 85, DOI: https://doi.org/10.22304/pjih.v4n1.a5

8 Indonesia, Law Number 28 of 2009 Concerning Regional Taxes and Regional Levies, State Gazette of the Republic of Indonesia (LNRI) Year 2009 Number 130, and Additional State Gazette (TLN) Number 5049, Article 1 point 10
} 
types of tax..$^{9}$

The Regional Revenues and Expenditures Budget (Anggaran Pendapatan dan Belanja Daerah/ "APBD") consists of regional tax proceeds, regional levy proceeds, regional enterprise proceeds, and other legitimate local business proceeds. ${ }^{10} \mathrm{~A}$ common problem faced by the Indonesian government is the source of regional revenues. ${ }^{11} \mathrm{In}$ contrast to national revenues from taxes, the proceeds of regional tax and regional levy revenues are recognized as inadequate and have a relatively small role in the APBD, particularly for district and town areas. Most of the APBD expenditure is funded by central allocation funds, which cannot be fully expected to cover all regional expenditure needs. ${ }^{12}$

The Regency/Municipal government has authority to issue regional regulation ("Perda") in the context of increasing Original Regional Revenues (Pendapatan Asli Daerah/ "PAD"), such as in determining tax and levy within the Unitary State of the Republic of Indonesia, specifically the authority of granting approval and facilities as well as licensing for investment. Upon the authority of the respective District/Town areas, the Regency/Municipal government competes in issuing Perda, among other things, related to parking fees, road lighting fees and licensing in the trade and investment industry, without taking into account other aspects. This in turn may hamper investment in their respective regions. ${ }^{13}$

In the latest development, the Central Government plans to include the issue of regional tax and regional levy as part of the Omnibus Law. This aims to rearrange regional authority in collecting taxes. It is expected that this effort will create equal tax treatment for investment activities in all regions, ${ }^{14}$ where there will be no more double (tax)/ investment will not be complicated. With regard to that, the Institute for Development of Economics and Finance (Indef) believes that the inclusion of regional tax in the Omnibus Law has the potential to reduce regional revenue. ${ }^{15}$

The Central Government responds that in order to regulate PAD remains well and in line with central government policy, the central government will coordinate with the

${ }^{9}$ Ratih Kumala, Analisis Efektifitas Pajak Reklame... Loc. Cit.

${ }^{10}$ Indonesia, Law Number 12 of 2019 Concerning Management of Regional Finances, State Gazette of the Republic of Indonesia (LNRI) Year 2019 Number 42, and Additional State Gazette (TLN) Number 6322, Article 31 paragraph (1).

11 Ludgardia Budiningsih, et.al, Implementasi Kebijakan Pemungutan Pajak Reklame Berdasarkan Peraturan Daerah (Perda) No. 2 Tahun 2011 Tentang Pajak Daerah di Kabupaten Sintang, Jurnal Tesis PMISUNTAN-PSIAN, 2013, p. 2, retrieved from https://www.neliti.com/id/publications/9438/implementasi-kebijakanpemungutan-pajak-reklame-berdasarkan-peraturan-daerah-per

12 Irwansyah Lubis, Kreatif Gali Sumber Pajak Tanpa Bebani Rakyat, PT Elex Media Komputindo, Jakarta, 2011, p. 14.

${ }^{13}$ Suradiyanto, Pembangunan Hukum Investasi Dalam Peningkatan Penanaman Modal Di Indonesia, DIH, Jurnal IImu Hukum, Vol. 11, No. 21, p. 31, retrieved from https://media.neliti.com/media/publications/240054pembangunan-hukum-investasi-dalam-pening-735a5fd7.pdf

14

http://www.klinikpajak.co.id/berita+detail/?id=berita+pajak++pajak+daerah+akan+diatur+ulang\%2C+indef\%3A+harus+hati-hati

15 https://www.antaranews.com/berita/1180876/indef-pajak-daerah-masuk-omnibus-law-pendapatanbisa-berkurang 
regional government associations. The rationalization of regional tax is aimed at creating a better business environment, employment and investment opportunities. The government will also formulate efforts so that regional governments can improve Perda more quickly through Regional Head Regulations. The reduction and exemption of regional taxes, up to regulation of income tax for national negotiable paper circulated on the international market will be regulated in the Omnibus Bill on Taxation. ${ }^{16}$

Based on the above, there 2 (two) issues that will be discussed in this writing, namely the arrangement of regional taxes and its effect on investment climate in Indonesia, as well as the provisions of regional tax in the Bill on Tax Provisions and Facilities for Strengthening the Economy.

The method used in this research is the normative legal research, i.e. a research conducted by examining library materials or secondary data in the form of various legal materials/references and non-legal materials/references. Sources of legal material in a broad sense include: 1) legal principles, 2) legal rules, 3) laws and regulations, 4) legal doctrine and teachings, 5) legal theories, 6) legal encyclopedias, 7) legal dictionaries, and 8) legal literatures. ${ }^{17}$ As first step in the research, the writer collected the documents needed as data, which consists of legal documents and non-legal documents.

Legal documents used as references and analyzed in this research are in the form of laws and regulations and/or other legal products that regulate matters related to the title of this research, such as Law Number 28 of 2009 Concerning Regional Taxes and Regional Levies, Law Number 12 of 2019 Concerning Management of Regional Finances, and Law Number 23 of 2014 Concerning Regional Government. Meanwhile, the non-legal documents that used in this research are in the form of Black Law Dictionary and articles obtained from the relevant online sites.

The data processing and analysis method used is descriptive qualitative method by describing the issues and facts which are explained in writing based on the literature/ library research supported by primary data, and analyzed using a normative juridical approach which finally allows conclusions to be reached.

\section{RESULTS AND DISCUSSION}

\section{A. Regional Tax and Investment}

\section{Regional Tax Regulations}

Regional autonomy in the unitary state as intended in Indonesia is the authority of region to regulate and manage its own government affairs as determined by law. Specifically, the regional government carries out government affairs which are its authority except for foreign affairs, defense, security, justice (yustisi), monetary and national fiscal and religious matters. ${ }^{18}$ One form of fiscal

16 https://www.hukumonline.com/berita/baca/It5dde113b5821e/indef--pajak-daerah-masuk-omnibuslaw-potensi-kurangi-pendapatan-daerah/

17 Nurul Qamar, et al., Metode Penelitian Hukum (Legal Research Methods), CV Social Politic Genius (SIGn), Makassar, 2017, hlm. 9.

18 Indonesia, Law Number 23 of 2014 Concerning Regional Government, State Gazette of the Republic of Indonesia (LNRI) Year 2014 Number 244, and Additional State Gazette (TLN) Number 5587, Article 10 paragraph (1). 
decentralization implementations is the determination of sources of revenue for regions that can be explored and used with their respective potential. ${ }^{19}$ The regional authority is manifested by collecting regional taxes and regional levies that are regulated by Law 28/2009 as partly amended based on Constitutional Court Decision Number 52 / PUU-IX / 2011, Constitutional Court Decision Number 46 / PUU-XII / 2014, Constitutional Court Decision Number 15 / PUU-XV / 2017, and Constitutional Court Decision Number 80 / PUU-XV / 2017.

As is the case with central tax, regional tax have an important role in the administration of state/government, either regulatory, budgetary, redistributive, and resource allocation functions, or combination of the four. In general, the function of regional tax is more directed to the allocation of resources in the context of providing services to the community, in addition to the regulatory function for control. Accordingly, the regional tax function can be divided into 2 (two) main functions, i.e. the budgetary function and the regulatory function. However, this distinction is not dichotomous. ${ }^{20}$

Josef Riwu Kaho opines that the characteristics of the regional tax are as follows: (a) Regional tax originates from the State Tax which is submitted to the region as regional tax; (b) Assignment is based on legislation; (c) Regional taxes are collected by the regions based on laws and/or other regulations. ${ }^{21}$ Rochmad Sumitro states that regional tax is a tax collected by autonomous regions. Whereas, debate on whether regional governments have the right to collect taxes always exists. Some agree that the regional government collect taxes and others disagree. To moderate these two opinions, various solutions emerged, one of which was Devas' opinion. ${ }^{22}$ Devas proposed five benchmarks for assessing regional tax, i.e. yield, equity, economic efficiency, ability to implement, and suitability as a local source. The five benchmarks have been used to assess regional tax in Indonesia, ${ }^{23}$ which are imposed through the Law 28/2009, among other things, motor vehicle tax, entertainment tax, hotel and restaurant tax, street lighting tax, company registration tax, advertising tax.

Based on the Law 28/2009, the Regional tax is divided into two (2) parts, i.e.:

a) Types of provincial Taxes consist of:

(1) Motor Vehicle Tax;

(2) Excise/Tax For Transfer of Ownership of Motor Vehicle;

(3) Motor Vehicle Fuel Tax;

\footnotetext{
${ }^{19}$ Machfud Sidik, Perimbangan Keuangan Pusat dan Daerah Sebagai Pelaksanaan Desentralisasi Fiskal, in Badan Pembinaan Hukum Nasional Kementerian Hukum Dan Hak Asasi Manusia RI, Analisis dan Evaluasi Tentang Pajak dan Retribusi Daerah, Badan Pembinaan Hukum Nasional, Jakarta, 2013, p. 6-7.

20 http://www.djpk.kemenkeu.go.id/wp-content/uploads/2018/08/pajak_daerah-1.pdf

21 Josef Riwu Kaho, Prospek Otonomi Daerah, PT Raja Grafindo, Jakarta, 2005, p. 131.

22 Agustinus Nusa, et. al, Potensi Pajak dan Retribusi Daerah di Kabupaten Yahukimo, Jurnal Kajian Ekonomi dan Keuangan Daerah/ Keuda, Vol. 2, No. 3, 2017, p. 3-4, retrieved from https://www.neliti.com/id/publications/217603/potensi-pajak-dan-retribusi-daerah-di-kabupaten-yahukimo

${ }^{23}$ Nick Devas, Keuangan Pemerintah Daerah di Indonesia, in Maria K. Tupamahu, et. al, Optimalisasi Potensi Pajak dan Retribusi dalam Meningkatkan Pendapatan Asli Daerah (PAD) Kota Ambon, Jurnal Manajemen Bisnis dan Inovasi, Vol. 6, No. 1, January 2019, p. 13-14, DOI: https://doi.org/10.35794/jmbi.v6i1.24270
} 
(4) Surface Water Tax;

(5) Cigarette Tax.

b) Types of district/town taxes consist of:

(1) Hotel Tax;

(2) Restaurant Tax;

(3) Entertainment Tax;

(4) Advertising Tax;

(5) Street Lighting Tax;

(6) Tax on Non-Metal Mineral and Rock;

(7) Parking Tax;

(8) Ground Water Tax;

(9) Tax on Swallows' Nests;

(10) Rural and Urban Land and Building Tax;

(11) Excise/Tax for Acquiring Right on Land and Building. ${ }^{24}$

\section{Regional tax and the Investment Climate}

Investment is required to support the development of a region given that sometimes a region does not have sufficient budget to carry out regional development. The necessity of the private sectors or investors involvement can be illustrated on a world scale, i.e. the World Development Report which states that $90 \%$ of the world's jobs are created by private businesses. ${ }^{25}$

Legal certainty in the administration of regional government is increasingly important since economic development greatly influences the investment climate which is expected to become regional development capital. The unsynchronization of regional and central policies is seen as an obstacle in optimizing investment in the regions. This is reflected in the occurrence of overregulation through the many overlapping and conflicting legal regulations due to the lack of an orderly regulation in the regions. Regional regulations that are intended to be a legal instrument for the implementation of government decentralization to drive development, as well as control against violations of regional development, has in fact become an obstacle to regional development, particularly in the area of investment friendly licensing governance. ${ }^{26}$

The symptom of over-regulation which is shown through the formation of excessive regional regulations has created a wilderness of regional regulations and resulted in the inefficient and ineffective administration of regional government in the economic and investment sectors. This has resulted in the absence of certainty for the regional government as the executor of the administration of government, as well as for the community and businesses in the implementation of economic activities and investments in the regions. Such

24 Indonesia, Law Number 28 of 2009 Concerning Regional Taxes... Op.Cit., Article 2 paragraph (1) and (2).

25 Winardi, Melihat Ulang Arah Politik Hukum di Daerah Pasca Otonomi dan Desentralisasi, Jurnal Konstitusi, July-December 2008, p. 137.

${ }^{26}$ Isharyanto and Nur Sulistiyaningsih, "Analisis Peraturan Daerah Bermasalah terkait dengan Tata Kelola Perizinan yang Ramah Investasi di Kota Surakarta", in Nunik Nurhayati and Galuh Wahyu Kumalasari, eds., Perizinan di Era Citizen Friendly, Pusat Studi Perizinan UMS dan Prosiding Seminar Nasional, Surakarta, 2017, p. 81-82. 
conditions have impeded investment climate and economic growth development programmed by the government. If the guaranty of security and legal certainty in the investment sector is low, investors will be reluctant or even afraid to invest their capital in the region. ${ }^{27}$

The Ministry of Home Affairs, driven by evaluations that have been made, has issued Instruction of the Minister of Home Affairs Number: 582/476/SJ concerning Revocation/Amendment of Regional Regulations, Regional Head Regulations, and Regional Head Decisions Inhibiting Bureaucracy and Investment Licensing. This instruction was set on 16 February 2016. Based on the Minister of Home Affairs Instruction, governors and regents/mayors throughout Indonesia have to immediately take steps to revoke/amend regional regulations, regional head regulations, and regional head decisions that hamper bureaucracy and licensing investment. The Regional Government Law has prepared sanctions in the event of regional government does not follow up on the the revocation. The provision of sanctions for regional governments is a new regulatory material that is not contained in previous legislation. There are two forms of sanctions that will be imposed on regional governments, i.e. administrative sanctions and postponement of the regional regulation draft evaluation. ${ }^{28}$

As a comparison, a study conducted in Central Java in 2013 finds a correlation between the imposition of regional taxes and investment, in which one of the conditions that could potentially be an inhibiting factor for domestic capital investment is the increasingly large tax burden per business unit or company. Tax per business unit that is borne by the entrepreneur significantly influences domestic capital investment, in a negative relationship. The higher tax burden per business unit makes the lower domestic capital investment. ${ }^{29}$ As in domestic capital investment, the taxation of foreign entrepreneurs/investors becomes a burden in investing. Tax per business unit that is borne by the entrepreneur significantly influences foreign capital investment in a negative relationship. The higher tax burden per business unit makes the lower foreign capital investment. ${ }^{30}$

\section{B. OMNIBUS BILL ON TAXATION}

\section{What is the Omnibus Law?}

Black Law Dictionary defines Omnibus Law, also known as Omnibus Bill as follows:

1. A single bill containing various distinct matters, usu. drafted in this way to force the executive either to accept all the unrelated minor provisions

\footnotetext{
${ }^{27}$ Isrok, Korelasi Peraturan Daerah (Perda) Bermasalah dengan Tingkat Investasi ke Tingkat Daerah, Jurnal Hukum, Vol. 16, No. 4, October 2009, p. 553, DOI: https://doi.org/10.20885/iustum.vol16.iss4.art7

28 https://www.hukumonline.com/berita/baca/lt575ff81fd70ea/begini-mekanisme-pencabutanperaturan-daerah/

29 Jan Hotman and Adolf B. Heatubun, "Analisis Dampak Pajak Daerah terhadap Pertumbuhan Ekonomi (Studi Kasus di Provinsi Jawa Tengah)", Laporan Penelitian Hibah Bersaing Perguruan Tinggi Universitas Terbuka, Maluku, 2013, p. 40.

30 Ibid., p. 42.
} 
or to veto the major provision.

2. A bill that deals with all proposals relating to a particular subject, such as an "omnibus judgeship bill" covering all proposals for new judgeships or an "omnibus crime bill" dealing with different subjects such as new crimes and grants to states for crime control. ${ }^{31}$

In short, Omnibus Law is a new law created to amend several laws at once. Roughly translated, the Latin word "omnibus" means "for all, for everybody." 32 Based on the definition in the Black Law Dictionary above, omnibus law is a bill that covers more than one aspect and combined into one law. The omnibus bill is complex rules and the process of its completion usually takes a long time since it contains a lot of material even though the subject, issue, and program are not always related. that:

Likewise, the Drafter Team of Bill on Job Creation Academic-Text states

Omnibus law is a practice of legislation drafting, which is mostly carried out in countries that adhere to a common law/anglo saxon system such as the United States of America, Canada, the United Kingdom, Philippines, and others. The process is called omnibus legislating and the product is called an omnibus bill. The word omnibus comes from Latin which means for everything. 33

Omnibus law, as a way of drafting regulations, is often used in countries with a common-law system. Noting its history in the United States of America, then the existence of this omnibus law stems from a series of events as follows: In Berger v. New York, the Supreme Court reversed a bribery conspiracy conviction that was based on evidence obtained by means of a court authorized "bug" installed in the defendant's office pursuant to a state statute. In Katz v. United States, the Supreme Court reversed a gambling conviction that was based on evidence obtained by means of a bug placed, without prior judicial authorization, upon the outside of a phone booth that the defendant had used. In both cases, the Court held electronic surveillance subject to the requirements of the fourth amendment. The constitutional defect found in Berger was that the statute contained inadequate procedural standards and safeguards. The Katz Court held that, although the bug would have been constitutional if prior judicial approval had been obtained, failure to obtain such approval was fatal. Title III of the Omnibus Crime Control and Safe Streets Act of 1968 was then enacted in an attempt to comply with Katz and Berger. Section 2518 of that title contains the procedural requirements for obtaining an "order" authorizing electronic surveillance, and section 2511(3) specifies some of the types of surveillance to

\footnotetext{
${ }^{31}$ Bryan A. Garner, et.al., eds., Black's Law Dictionary Ninth Edition, West Publishing Co., St. Paul, 2009, p. 186.

32 https://www.minnpost.com/politics-policy/2017/03/everything-you-need-know-about-omnibus-billsand-why-theyre-so-popular-minne/

33 Indonesia, Academic Draft of Job Creation Bill, p. 24.
} 
which the title does not extend. ${ }^{34}$

Then the question is: in the event Indonesia adheres to the Civil Law System, can the omnibus law be applied? The answer is yes, omnibus law can be used to overcome the problem of complexity and overlapping regulations in Indonesia, although laws and regulations theory in Indonesia does not recognize the concept of omnibus law. The main task undertaken in compiling the omnibus law is to horizontally and vertically analyze legislations, from the highest to the lowest hierarchy, so that synchronization and harmony are guaranteed. ${ }^{35}$ The concept of omnibus law in its establishment mechanism shall follow the procedures set out in Law Number 15 of 2019 concerning the Formation of Legislation, ranging from planning, drafting, discussion, to its legalization. On one side, the omnibus law scheme is considered too sectoral and narrow. However, on the other hand it is good for stimulating investment and exports. In fact, if the omnibus law is applied, it shall have a significant impact on better economic growth. ${ }^{36}$

Indonesia can learn from the Philippines which has applied omnibus law in the investment sector by issuing an Omnibus Investment Code of 1987. Through the Omnibus Investment Code of 1987, investors are given a number of incentives and basic rights that guarantee their businesses in the Philippines. Omnibus Investment Code of 1987 is a kind of codification in the investment sector so that all investment-related arrangements shall refer to the Omnibus Investment Code of 1987. ${ }^{37}$ Japan, which legal system is based on the civil law system and adheres to the presidential system can also be seen as a good comparison. During the last decade of the twentieth century, the government of Japan achieved a significant degree of decentralization, the high point of which was the 1999 Omnibus Law of Decentralization. The legislative process for the enactment of the Omnibus Law was complex in the extreme, with 475 laws, 440 cabinet orders, 507 ministerial orders, and 186 public notices. ${ }^{38}$

The conception of the omnibus law and consolidation law is considered as an appropriate solution for the simplification of regulations and a constructive method concept for legislation drafting without ignoring the rules in Law Number 12 of 2011 concerning Formation of Laws and Regulations as amended by Law

\footnotetext{
${ }^{34}$ Thomas I. Sheridan, Electronic Intelligence Gathering and the Omnibus Crime Control and Safe Streets Act of 1968, Fordham Law Review, Vol. 44, Issue 2, 1975, p. 331-332, retrieved from https://ir.lawnet.fordham.edu/flr/vol44/iss2/5

35 Yustinus Prastowo, "Mujarabkah Omnibus Law sebagai Obat Lesu Ekonomi?”, (presented at the Regular Tax Discussion for Center for Indonesia Taxation Analysis, Jakarta, 7 November 2019), p. 29.

${ }^{36} \mathrm{Mh} / \mathrm{sf}$, Skema 'Omnibus Law' Sangat Sektoral, in Agnes Fitryantica, Harmonisasi Peraturan PerundangUndangan Indonesia melalui Konsep Omnibus Law, Jurnal Gema Keadilan, Vol. 6, Edition III, October-November 2019, p. 312, DOI: https://doi.org/10.14710/gk.6.3.300-316

37 Vincent Suriadinata, Penyusunan Undang-Undang di Bidang Investasi: Kajian Pembentukan Omnibus Law di Indonesia, Jurnal Refleksi Hukum, Vol. 4, No. 1, October 2019, p. 118, DOI: https://doi.org/10.24246/jrh.2019.v4.i1.p115-132

38 Furukawa Shun'ichi, "Decentralization in Japan", in Shun'ichi Furkawa and Toshihiro Menju, eds., Japan's Road to Pluralism: Transforming Local Communities in the Global Era, Japan Center for International Exchange, Tokyo, 2003, p. 21-45.
} 
Number 15 of 2019 concerning Amendments to Law Number 12 of 2011 concerning Formation of Laws and Regulations. Apart from the potential loopholes of the two methods, the transplantation of the legal system can be considered as an alternative solution to simplify regulation and deregulation of laws and regulations. ${ }^{39}$ In fact, Indonesia has adopted a policy similar to omnibus bills. In President Jokowi's first term, he instructed all ministries and agencies to conduct regulation simplification, which in essence is similar to an omnibus bill. The government also passed Government Regulation Number 24 of 2018 concerning Online Single Submission (OSS), which in practice is similar to an omnibus bill. ${ }^{40}$

\section{Tax Facility Law 2020 (Omnibus Bill on Taxation)}

The Government through the Minister of Finance has submitted a Bill on Tax Provisions and Facilities for Strengthening the Economy or better known as the omnibus bill on taxation to the House of Representatives on 31 January 2020. The academic text of the omnibus bill on taxation states that there are nine laws included in the discussion, i.e.:

1. Law concerning General Provisions and Procedures of Tax;

2. Law concerning Income Tax;

3. Law concerning Value Added Tax;

4. Law concerning Customs;

5. Law concerning Excise Duty;

6. Law concerning Electronic Information and Transaction;

7. Law concerning Investment;

8. Law concerning Regional Taxes and Regional Levies;

9. Law concerning Regional Government.

The omnibus bill on taxation has ten scopes of legal material, including the income tax rates of the domestic corporate and permanent establishment, the tax treatment of dividends and other income from abroad, the treatment of income tax tariff on interest, arrangements of the imposition of income tax for individual taxpayers, arrangements of input taxes crediting, arrangements of administrative sanctions, arrangements of the interest amount, arrangements of granting tax facilities, tax treatment in trading activities through electronic systems, and arrangements regarding regional tax and regional levy. ${ }_{4}^{41}$

The academic text of the Omnibus Bill on Taxation states that the tax incentives are intended to reduce the tax burden that must be borne by the Taxpayer so that there is room for domestic funding to increase investment and also increase foreign direct investment (FDI). In other words, this is expected to strengthen the national economy by increasing both domestic and foreign investment funding. Then it can create the development and deepening of

\footnotetext{
${ }^{39}$ Ahmad Ulil Aedi, et. al, Arsitektur Penerapan Omnibus Law Melalui Transplantasi Hukum Nasional Pembentukan Undang-Undang, Jurnal Ilmiah Kebijakan Hukum, Vol. 14, No. 1, March 2020, p. 5, DOI: http://dx.doi.org/10.30641/kebijakan.2020.V14.1-18

${ }^{40}$ https://amcham.or.id/en/news/detail/omnibus-bills-how-do-they-work-

41 https://money.kompas.com/read/2020/02/06/115349726/omnibus-law-soal-perpajakan-berisi-9uu?page=all
} 
financial markets, legal certainty for tax subjects, ensure business continuity, and encourage taxpayer's voluntary compliance. Furthermore, it is intended to create justice in the domestic business climate, encouraging national scale priority sectors by providing facilities, protection, as well as simple and fair arrangements. ${ }^{42}$

Similar measures have also been taken by other countries to stimulate the economy. The United States of America has carried out tax reforms known as the Tax Cut and Jobs Act (TCJA) in 2017 which was proven to help economic growth and job creation. ${ }^{43}$ Some features of the tax reform include the reduction of Corporate Income Tax rates, various tax reliefs for individuals, the implementation of a territorial tax regime on certain income of companies from abroad, and other reliefs. Various countries also participated in tax relaxation, such as the United Kingdom, Denmark, Ireland, Canada, and other OECD countries. For example, reductions in Corporate Income Tax rates were carried out by France, Luxembourg, Norway, and the Netherlands between 2019 and 2021.44

With regard to Regional Taxes and Regional Levies, in practice, the Regional Government tends to set a maximum rate regulated in Law 28/2009 without considering its impact on the ease of doing business and investment. Besides, the Law on Regional Taxes and Regional Levies gives authority to regional heads in determining the basis for taxation according to provincial and district/town taxation authority. Local policies, including those related to regional taxes, are occasionally designed not in line with central government policies. These things cause differences in investment costs that must be borne by investors in different regions so that interest to investment is reduced and results in uneven investment coming to the region as well. This is one of the main reasons for the Government to consider that the Omnibus Bill on Taxation is necessary. ${ }^{45}$

In the event Omnibus Bill on Taxation is passed, Central Government can stipulate one tax rate for regional tax and regional levy, to be implemented nationally. Central Government can also monitor and evaluate the regional tax and regional levy, which prevents ease of doing business. ${ }^{46}$ The stipulation of certain tariffs is carried out to implement national strategic programs in the form of national fiscal policies and shall be regulated through Presidential Regulation. Regional Government shall enact the tariffs set forth in the Presidential Regulation no later than 3 months after the Presidential Regulation is

42 Indonesia, Academic Draft of General Provisions and Tax Facilities for Strengthening the Economy Bill, p. 14.

${ }^{43}$ Anil Kumar, Did Tax Cuts and Jobs Act Create Jobs and Stimulate Growth? Early Evidence Using StateLevel Variation in Tax Changes, in Darussalam, et. al, Policy Note: Omnibus Law Ketentuan \& Fasilitas Perpajakan untuk Penguatan Perekonomian: Suatu Catatan, DDTC Fiscal Research, March 2020, p. 2, retrieved from https://ddtc.co.id/policynote/policynote-01/files/basic-html/index.html

\footnotetext{
44 Ibid.

45 Indonesia, Academic Draft of General Provisions and Tax Facilities... Op.Cit., p. 13-14.

${ }^{46}$ Indonesia, Bill on General Provisions and Tax Facilities for Strengthening the Economy, Article 21.
} 
promulgated. ${ }^{47}$ Furthermore, based on the Omnibus Bill on Taxation, facility that can be given in relation to regional tax is in the form of relief, reduction and/ or exemption of regional tax. ${ }^{48}$ It shall further be regulated in the Regional Head Regulation. ${ }^{49}$ Taxpayers that invest in certain business sectors and/or in certain regions, which are given high priority on the national scale can be given tax allowance incentive. ${ }^{50}$

The rationalization of regional tax and regional levy is necessary in the context of increasing the role of the central government to control the burden and administration of regional tax and regional levy (LTL) so that the LTL policy is in line with the policies of the central government in order to create a conducive climate for the business world. ${ }^{51}$ National fiscal policy is exemplified as follows, based on Law 28/2009 Motor Vehicle Fuel Tax (MVFT) is set at a maximum of $10 \%$ (ten percent). The determination of the tariff becomes the authority of the Province and stipulated in the Provincial Regulation concerning Regional Taxes and Regional Levies. In the context of stabilizing the price of subsidized motor vehicle fuel, the Government can set the MVFT rate of 5\% (five percent) nationally, which is determined by Presidential Regulation. ${ }^{52}$

The evaluation of Regional Regulations by the central government is in the form of: a) evaluation of Provincial/Regency/Municipal Regulations on Regional Taxes and Regional Levies; and b) evaluation of the implementation of Regional Regulations on Regional Taxes and Regional Levies that have been stipulated. The mechanism is carried out in the following manner: the draft of Provincial/Regency/Municipal Regulations which has been agreed with the People's Legislative Council shall be submitted to the minister who carries out domestic government affairs (home affairs minister) and Finance Minister ${ }^{53}$ prior to a stipulation by governor/regent/mayor. Home Affairs minister shall then evaluate the draft in accordance with statutory provisions and Finance Minister examine the compatibility between the Draft of Regional Regulations to the provisions of the higher laws and national fiscal policies. The evaluation result from Finance Minister is either recommendation of: a) the process of establishing the said draft of Regional Regulation can be continued, or b) the draft of Regional Regulation shall be adjusted to the evaluation results; such result shall be delivered to the Home Affairs Minister. ${ }^{54}$

The regional regulation and its subordinate legislation shall be submitted to both ministers no later than 7 (seven) working days after they are determined. The Finance Minister can supervise the Regional Regulation on Regional Taxes and Regional Levies

\footnotetext{
47 Ibid., Article 22.

48 Ibid., Article 16 par (9).

49 Ibid., Article 16 par (11).

50 Ibid., Article 16 par (12).

51 Indonesia, Academic Draft of General Provisions and Tax Facilities... Op. Cit., p. 16.

52 Indonesia, Bill on General Provisions and Tax Facilities... Op. Cit., Elucidation of Article 22 paragraph (1).

53 Ibid., Article 1 point 19.

54 Ibid., Article 23.
} 
and its subordinate legislation by evaluating them. If the said regulation deemed as a hindrance to the ease of doing business, then the regional government is required to make changes to the Regional Regulation and/or its subordinate legislation no later than 6 (six) months after the results of the evaluation are published. The government has prepared sanctions in the event Regional Government fails to deliver the Regional Regulation and its subordinate regulation to the ministers or fails to make the required changes, i.e. postponement and/or deduction of funds transfer (dana transfer) to the regions and/or other sanctions in accordance with the prevailing law and regulations. ${ }^{55}$

\section{CONCLUSION}

1. Domestic and foreign investments are strongly hampered by the company's tax burden. The budgetary, regulatory, and resource allocation function of tax are still relatively small manifested in their implementation when regional tax revenues are pegged up that it does not lead investors to increase investments.

2. The Omnibus Bill on Taxation is a good breakthrough. If passed, it would be the most significant change to the Indonesian tax system in some time, given that it has been over 10 years since the last amendments to the three key Indonesian tax laws. The existence of the Omnibus Bill is expected to encourage regulatory enhancements, improve the investment climate, and ultimately be able to increase tax revenue. However, it is necessary to ensure the harmonization of regulations as well as the clarity of intervention and/or coordination procedures between the central and regional government so that the process of rationalizing the regional tax policy may run smoothly as expected.

\section{REFERENCES}

\section{Book}

Badan Pembinaan Hukum Nasional Kementerian Hukum Dan Hak Asasi Manusia RI. 2013. Analisis dan Evaluasi Tentang Pajak dan Retribusi Daerah. Jakarta: Badan Pembinaan Hukum Nasional.

Dinas Pendapatan Daerah Kota Malang. 2012. Info PAD Kota Malang. Malang: Dinas Pendapatan Daerah Kota Malang.

Furkawa, Shun'ichi and Toshihiro Menju. eds. 2003. Japan's Road to Pluralism: Transforming Local Communities in the Global Era. Tokyo: Japan Center for International Exchange.

Garner, Bryan A., et.al. eds. 2009. Black's Law Dictionary Ninth Edition. St. Paul: West Publishing Co.

Ismail, Tjip. 2008. Pengaturan Pajak Daerah di Indonesia. Jakarta: Yellow Printing.

Kaho, Josef Riwu. 2005. Prospek Otonomi Daerah. Jakarta: PT Raja Grafindo.

Lubis, Irwansyah. 2011. Kreatif Gali Sumber Pajak Tanpa Bebani Rakyat. Jakarta: PT Elex Media Komputindo.

55 Ibid., Article 23. Also see https://bisnis.tempo.co/read/1306236/melalui-omnibus-law-pemerintahakan-atur-tarif-pajak-di-daerah 
Nurhayati, Nunik and Galuh Wahyu Kumalasari. eds. 2017. Perizinan di Era Citizen Friendly. Surakarta: Pusat Studi Perizinan UMS dan Prosiding Seminar Nasional.

Soemitro, Rochmat. 1992. Pengantar Singkat Hukum Pajak. Bandung: Eresco.

\section{Journal and Paper}

Aedi, Ahmad Ulil, et. al. 2020. Arsitektur Penerapan Omnibus Law Melalui Transplantasi Hukum Nasional Pembentukan Undang-Undang. Jurnal Ilmiah Kebijakan Hukum, 14(1), 1-18. http://dx.doi.org/10.30641/kebijakan.2020.V14.1-18

Budiningsih, Ludgardia, et.al. 2013. Implementasi Kebijakan Pemungutan Pajak Reklame Berdasarkan Peraturan Daerah (Perda) No. 2 Tahun 2011 Tentang Pajak Daerah di Kabupaten Sintang. Jurnal Tesis PMIS-UNTAN-PSIAN, 1-21. Retrieved from https://www.neliti.com/id/publications/9438/implementasikebijakan-pemungutan-pajak-reklame-berdasarkan-peraturan-daerah-per

Cahyadini, Amelia. 2017. Pemisahan Peraturan Daerah Tentang Pajak dan Izin Reklame Sebagai Upaya Memaksimalkan Penerimaan Pajak. PJIH, 4(1), 84-103. https://doi.org/10.22304/pjih.v4n1.a5

Darussalam, et. al. 2020. Policy Note: Omnibus Law Ketentuan \& Fasilitas Perpajakan untuk Penguatan Perekonomian: Suatu Catatan. DDTC Fiscal Research, 1-23. Retrieved from https://ddtc.co.id/policynote/policynote-01/files/basichtml/index.html

Fitryantica, Agnes. 2019. Harmonisasi Peraturan Perundang-Undangan Indonesia melalui Konsep Omnibus Law. Jurnal Gema Keadilan, 6(III), 300-316. https://doi.org/10.14710/gk.6.3.300-316

Hotman, Jan and Adolf B. Heatubun. "Analisis Dampak Pajak Daerah terhadap Pertumbuhan Ekonomi (Studi Kasus di Provinsi Jawa Tengah)", Laporan Penelitian Hibah Bersaing Perguruan Tinggi Universitas Terbuka, Maluku, 2013, p. 40.

Isrok. 2009. Korelasi Peraturan Daerah (Perda) Bermasalah dengan Tingkat Investasi ke Tingkat Daerah. Jurnal Hukum, 16(4), 551-568. https://doi.org/10.20885/iustum.vol16.iss4.art7

Kumala, Ratih. 2019. Analisis Efektifitas Pajak Reklame Dalam Meningkatkan Penerimaan Pajak Daerah di Kota Bekasi. Jurnal Reformasi Administrasi, 6(1), 38-41. Retrieved from ojs.stiami.ac.id > reformasi > article > download

Nusa, Agustinus, et. al. 2017. Potensi Pajak dan Retribusi Daerah di Kabupaten Yahukimo. Jurnal Kajian Ekonomi dan Keuangan Daerah/ Keuda, 2(3), 1-19. Retrieved from https://www.neliti.com/id/publications/217603/potensi-pajak-danretribusi-daerah-di-kabupaten-yahukimo

Prastika, Yolanda Nurlita, et. al. 2015. Analisis Efektivitas Pendapatan Pajak Reklame dan Kontribusinya Pada Pendapatan Pajak Daerah (Studi Pada Dinas Pendapatan Daerah Kota Malang). Jurnal Perpajakan (JEJAK), 6(2), 1-6. Retrieved from 
http://perpajakan.studentjournal.ub.ac.id/index.php/perpajakan/article/vie $\mathrm{w} / 197$

Prastowo, Yustinus. “Mujarabkah Omnibus Law sebagai Obat Lesu Ekonomi?” Paper presented at the Regular Tax Discussion for Center for Indonesia Taxation Analysis, Jakarta, 7 November 2019.

Sheridan, Thomas I. 1975. Electronic Intelligence Gathering and the Omnibus Crime Control and Safe Streets Act of 1968. Fordham Law Review, 44(2), 331-354. Retrieved from https://ir.lawnet.fordham.edu/flr/vol44/iss2/5.

Suradiyanto. 2015. Pembangunan Hukum Investasi dalam Peningkatan Penanaman Modal di Indonesia. DIH, Jurnal Ilmu Hukum, 11(21), 25-32. Retrieved from https://media.neliti.com/media/publications/240054-pembangunanhukum-investasi-dalam-pening-735a5fd7.pdf

Suriadinata, Vincent. 2019. Penyusunan Undang-Undang di Bidang Investasi: Kajian Pembentukan Omnibus Law di Indonesia. Jurnal Refleksi Hukum, 4(1), 115134. https://doi.org/10.24246/jrh.2019.v4.i1.p115-132

Tupamahu, Maria K., et. al. 2019. Optimalisasi Potensi Pajak dan Retribusi dalam Meningkatkan Pendapatan Asli Daerah (PAD) Kota Ambon. Jurnal Manajemen Bisnis dan Inovasi, 6(1), 11-30. https://doi.org/10.35794/jmbi.v6i1.24270.

Winardi. 2008. Melihat Ulang Arah Politik Hukum di Daerah Pasca Otonomi dan Desentralisasi. Jurnal Konstitusi, 130-159.

\section{Laws and Regulations}

Indonesia, Law Number 12 of 2019 Concerning Management of Regional Finances, State Gazette of the Republic of Indonesia (LNRI) Year 2019 Number 42, and Additional State Gazette (TLN) Number 6322

Indonesia, Law Number 23 of 2014 Concerning Regional Government, State Gazette of the Republic of Indonesia (LNRI) Year 2014 Number 244, and Additional State Gazette (TLN) Number 5587.

Indonesia, Law Number 28 of 2009 Concerning Regional Taxes and Regional Levies, State Gazette of the Republic of Indonesia (LNRI) Year 2009 Number 130, and Additional State Gazette (TLN) Number 5049.

Indonesia, Bill on General Provisions and Tax Facilities for Strengthening the Economy.

Indonesia, Academic Draft of General Provisions and Tax Facilities for Strengthening the Economy Bill.

Indonesia, Academic Draft of Job Creation Bill.

\section{Website}

Ananti, Ridha. 2019. Pajak Daerah akan Diatur Ulang, Indef: Harus Hati-Hati. Accessed on April 5, 2020, from http://www.klinikpajak.co.id/berita+detail/?id=berita+pajak+-

+pajak+daerah+akan+diatur+ulang\%2C+indef\%3A+harus+hati-hati 
Bierschbach, Briana. 2017. Everything you need to know about omnibus bills, and why they're so popular at the Minnesota Legislature. Accessed on May 9, 2020, from https://www.minnpost.com/politics-policy/2017/03/everything-you-needknow-about-omnibus-bills-and-why-theyre-so-popular-minne/

Direktorat Jenderal Perimbangan Keuangan. 2018. Pajak Daerah. Accessed on April 6, 2020, from http://www.djpk.kemenkeu.go.id/wpcontent/uploads/2018/08/pajak_daerah-1.pdf.

Hendartyo, Muhammad. 2020. Melalui Omnibus Law, Pemerintah Akan Atur Tarif Pajak di Daerah. Accessed on April 8, 2020, from https://bisnis.tempo.co/read/1306236/melalui-omnibus-law-pemerintahakan-atur-tarif-pajak-di-daerah

Lie, Peter Sean. 2020. Omnibus Bills: How do they Work? Accessed on May 9, 2020, from https://amcham.or.id/en/news/detail/omnibus-bills-how-do-they-work-

Santoso, Yusuf Imam. 2020. Omnibus Law soal Perpajakan Berisi 9 UU. Accessed on April 8 , 2020 , from https://money.kompas.com/read/2020/02/06/115349726/omnibus-lawsoal-perpajakan-berisi-9-uu?page=all

Wiguna, Dewa Ketut Sudiarta. 2019. Indef: Pajak daerah masuk Omnibus Law, pendapatan bisa berkurang. Accessed on May 8, 2020, from https://www.antaranews.com/berita/1180876/indef-pajak-daerah-masukomnibus-law-pendapatan-bisa-berkurang

Yoz. 2016. Begini Mekanisme Pencabutan Peraturan Daerah. Accessed on April 7, 2020, from https://www.hukumonline.com/berita/baca/lt575ff81fd70ea/beginimekanisme-pencabutan-peraturan-daerah/

Yozami, M. Agus. 2019. Indef: Pajak Daerah Masuk Omnibus Law Potensi Kurangi Pendapatan Daerah. Accessed on April 5, 2020, from https://www.hukumonline.com/berita/baca/lt5dde113b5821e/indef-pajak-daerah-masuk-omnibus-law-potensi-kurangi-pendapatan-daerah/ 